\title{
Associated Risk Factors of Non-Communicable Disease in Three Sites across Ivory Coast: An Urban (Cocody), Peri-Urban (Abobo) and Rural (Yocoboué) Area
}

\author{
Nina Laurette Ahouéfa ${ }^{1}$, Ibrahima Cissé2 ${ }^{2}$ Lêniféré Chantal Soro ${ }^{3}$, Audrey Herbert Yépié1, \\ Jean Jacques Diagou1, Jean-Baptiste Kouamé Yao', Louise Anin Atchibri' \\ ${ }^{1}$ Laboratory of Nutrition and Food Safety, Department of Food Science and Technology, University of Nanguy Abrogoua, \\ Abidjan, Ivory Coast \\ ${ }^{2}$ Laboratory of Industrial Process Synthesis and Environment and new energies, National Polytehnic Institute of Houphouët \\ Boigny, Yamoussoukro, Ivory Coast \\ ${ }^{3}$ Laboratory of Nutrition and Food Safety, University of Man, Man, Ivory Coast \\ Email: laurette.nina2017@gmail.com
}

How to cite this paper: Ahouéfa, N.L., Cissé, I., Soro, L.C., Yépié, A.H., Diagou, J.J., Yao, J.-B.K. and Atchibri, L.A. (2021) Associated Risk Factors of Non-Communicable Disease in Three Sites across Ivory Coast: An Urban (Cocody), Peri-Urban (Abobo) and Rural (Yocoboué) Area. Food and Nutrition Sciences, 12, 462-478. https://doi.org/10.4236/fns.2021.125036

Received: March 25, 2021

Accepted: May 23, 2021

Published: May 26, 2021

Copyright $\odot 2021$ by author(s) and Scientific Research Publishing Inc. This work is licensed under the Creative Commons Attribution International License (CC BY 4.0).

http://creativecommons.org/licenses/by/4.0/ (c) (i) Open Access

\section{Abstract}

Introduction: The prevalence of Non-communicable diseases (NCDs) has increased so it's becoming a global public health problem. This problem is also threatening in Sub-Sahara Africa (SSA) country including Ivory Coast. Ivory Coast is a country of 22.6 million people experiencing rapid economic development and social change. All development is typically associated with an increase in non-communicable disease (NCD) risk factors. Our study aimed to determine the prevalence and associated factors of the major risk factors of NCDs among the population of Cocody, Abobo and Yocoboué in the Ivory Coast. Methods: A descriptive and analytical cross-sectional study was conducted and involved 1146 adults of 19 to 60 years from general population in Cocody (urban), Abob (peri-urban) and Yocoboué (rural). The WHO STEPS risk factor survey has been changed a bit and was administered. it contains anthropometric and biochemical measures. Results: The prevalence of NCD risk factors was markedly different across the three sites particularly between urban (Cocody) and rural (Yocoboué) areas. The overall prevalence estimates of the risk factors were $15.2 \%$ for current smoking, $57.71 \%$ for harmful use of alcohol, $58.84 \%$ for low physical activity, $24.71 \%$ for sedentariness (sitting at least $7 \mathrm{~h}$ ), $69.45 \%$ for skipping breakfast, $61 \%$ for having late dinner and 36\% for snacking. Concerning biological risk factor we noticed $40.95 \%$ for Overweight/obesity, $52.96 \%$ for abdominal obesity, $14.61 \%$ for raised blood pressure, $23.37 \%$ for raised blood sugar and 18.51 low HDL-C. Being female has 
an important associated with an increased risk for having abdominal obesity (OR: 25.7) and being overweight or obese (OR: 11.3), suffering from hypertension increased with age, 30 - 39 years (OR 8.45), 40 - 49 years (OR 13.4) and 50 years and above (OR 24.6). Conclusion: Adult residents in the two (Urban and peri-urban) of three different areas are developing high-risk NCDs, particularly Cocody's population. At the end, we observed among participants that the female gender, living in urban areas and clustering are the most concerned by non-communicable disease risk factors. To reach the goal, preventive and therapeutic interventions are needed among the targeted population.

\section{Keywords}

Health, Chronic Non-Communicable Diseases, Risk Factors, Adult, Ivory Coast

\section{Introduction}

Human food has evolved over time and these changes are adapted to the lifestyle and environment evolution. However, this development retains the main goal of ensuring people physiological needs and good health [1].

Food and nutritional transitions have been characterized by the most marked changes such as the passage from hunting and gathering to the era of agriculture and breeding or that of a period of recurrent famine to a greater food prosperity one [2] [3].

The industrialized societies are generally confronted today with a growing challenge of imbalance between the abundance of food supplies on the one hand and the considerable drop in the energy needs of individuals [4].

The nutrition transition refers to the changes that populations experience in the quality and quantity of dietary behaviors and patterns. These changes go hand in hand with other lifestyle-related factors such as physical activity, work and family environments, and general health and socioeconomic well-being, all of which ultimately influence energy expenditure [5].

This might concern developed countries facing an incredible diversity and quantity of foodstuffs, but surveys in developing and low incomes countries showed that the rate of obesity and non-communicable diseases (NCDs) are increased [6].

In 2012, the World Health Organization have revealed that approximately $46 \%$ of all NCD-related deaths in 2012 were due to cardiovascular diseases (CVDs), followed by cancers (22\%), respiratory disease (11\%) and diabetes (4\%) [7].

About low and middle-income countries (LMICs), it's noted nearly $80 \%$ of NCD-related deaths and $82 \%$ of all NCDs premature deaths occur [7].

Ivory Coast is considered as a lower-middle-income country, which is in rapid economic growth [8]. Surveys have shown that this kind of country is going through an epidemiological transition which results in the increasing prevalence 
of NCDs and their risk factors [9].

The available evidence suggests this pattern is changing among those adult populations with longer exposure to modernisation. The latter is leading to rapid lifestyle changes associated with increases in CVD and diabetes [10].

The present study was designed to provide information on the magnitude of the NCD risk factors among the Ivorian adult population and a baseline for monitoring the trends, guiding decision making, and implementing appropriate interventions. To reach this goal, the study has concerned three different sociodemographic populations of Ivory Coast: an urban (Cocody), peri-urban (Abobo) and rural (Yocoboué) area.

\section{Material and Methods}

\subsection{Study Type and Population}

A descriptive and analytical cross-sectional study of a representative sample was conducted between August and November 2018. The study population concerned 1146 adults aged of 19 to 60 years old. These were men and women, living in urban area (Cocody), a peri-urban area (Abobo) and a rural locality in the south of Côte d'Ivoire (Yocoboué). To be Included on the study, participant should have living in the study area for at least 6 months, being aged 19 to 60 years, and having given informed consent. Participants who were excluded were those with disabilities (mentally deficient subjects) to answer questions, pregnant and breastfeeding's women and people diagnosed chronic diseases.

\subsection{Conduct of Study}

To collect data, we have used the World Health Organization (WHO) recommended surveillance of common risk factors with the "STEPwise" approach. Thus, STEPS approach focuses on the collection of data on key risk factors of major NCDs. It includes three sequential phases.

(Step 1) consists of collection on socio-demographic variables and behavioral risk factors by using of semi structured, interviewer-administered questionnaires [11].

(Step 2) It's question of obtaining clinical measurements such as Height (measured with a calibrated meter rule), Weight (using a standard weighing scale (TEFAL bodymaster). Body mass index (BMI) was derived by dividing weight (kg) by height squared $\left(\mathrm{m}^{2}\right)$ [12]. The waist circumference was obtained by using a nonextendable measuring tape [13].

(Step 3) this step concerns acquiring of biochemical measurements like blood pressure (Omron M5-I) [14], blood glucose, and high density lipoprotein (HDL-C [14]. We informed participants to have an overnight fasting $12 \mathrm{~h}$ before the day of data collection.

\subsection{Dependent and Independent Variables}

The dependent variables of this study concerned overweight and obesity, abdo- 
minal obesity, raised blood pressure and raised blood sugar and low HDL-C. Whereas, socio-demographic characteristics and behavioural risk factors were the independent variables.

\subsection{Statistical Analysis}

Data were inputted and cleaned using the IBM SPSS version 20 (SPSS Inc, Chicago, IL). The results were expressed as percentage. The $t$ tests and $\chi^{2}$ tests were performed to analyse statisticals differences.

Differences among rural, peri-urban and urban subjects were assessed using $\chi^{2}$ tests or 1-way analysis of variance (ANOVA) with Tukey post hoc test [15].

The multivariate logistic regression analyses were performed to identify the associated factors of overweight and obesity, abdominal obesity, raised blood pressure, raised blood sugar and low HDL-C, and the socio-demographic variables and behavioural risk factors.

\subsection{Ethical Considerations}

The Ethical approval for the study was given by the Ivory Coast State Ministry of Health Ethical Committee. Written and informed consent was obtained from each participant before them involving in the research. The principles laid down in the Declaration of Helsinki have been followed during the study protocol and conduct. Data were collected anonymously.

\section{Results}

\subsection{Caracteristics of Participants}

A total of 1146 people were surveyed. Women accounted for $60.03 \%$ of this population. The mean age was $38.72 \pm 8.5$ years. Across the sites, the most important of participants (49\%) has between 30 - 39 years old. The education level was significantly higher in the urban area (84.4\% in Cocody) than peri-urban area (72.4\% in Abobo) and rural area (45\% in Yocoboué). About one half of the respondents $(47.62 \%)$ were self-employed. This status concerned most of the participants of the peri-urban area (Abobo, 50\%) and rural area (Yocoboué, 57\%) (See Table 1).

\subsection{Prevalence of NCDs Behavioural Risk Factors}

The finding results about the behavioural risk factor are on Table 2.

\section{Tobacco consumption}

The overall prevalence of current smoking was $15.2 \%$. The prevalence of smoking among peri-urban (Abobo) population is higher (19.20\%) than urban (Cocody; 16.90\%) and rural (Yocoboué; 9.30\%) area.

The prevalence of tobacco users increased between 19 - 39 years old $(16.53 \%$ $18.86 \%)$ and decreased among older persons aged 40 and above $(12.39 \%$ 9.19\%).The prevalence of smoking was also significantly higher among males $34.93 \%$ than females $2.22 \%$. 
Table 1. Characteristics of study subjects.

\begin{tabular}{|c|c|c|c|}
\hline \multirow{2}{*}{$\begin{array}{l}\text { Sociodemographics } \\
\text { factors }\end{array}$} & \multicolumn{2}{|c|}{ Urban area } & \multirow{2}{*}{$\begin{array}{c}\text { Rural area } \\
\text { Yocoboué }(\mathrm{n}=378)\end{array}$} \\
\hline & Cocody $(n=384)$ & Abobo $(n=384)$ & \\
\hline \multicolumn{4}{|l|}{ Gender (\%) } \\
\hline Male & 144 & 163 & 151 \\
\hline Female & 240 & 221 & 227 \\
\hline Total & 384 & 384 & 378 \\
\hline \multicolumn{4}{|l|}{ Age group (\%) } \\
\hline $19-29$ & 30.2 & 38.00 & 36.3 \\
\hline $30-39$ & 48.2 & 49.00 & 49.7 \\
\hline $40-49$ & 13.3 & 10.40 & 8.00 \\
\hline $50-60$ & 8.3 & 2.60 & 6.00 \\
\hline \multicolumn{4}{|l|}{ Education level (\%) } \\
\hline No education & 15.60 & 27.6 & 55.00 \\
\hline Formal education & 84.40 & 72.4 & 45.00 \\
\hline Primary & 13.00 & 24.8 & 28.00 \\
\hline Secondary & 38.00 & 26.5 & 16.00 \\
\hline High & 33.40 & 21.1 & 01.00 \\
\hline \multicolumn{4}{|l|}{ Professional status (\%) } \\
\hline Unemployed & 7.00 & 16.00 & 10.00 \\
\hline Houseswives & 2.00 & 12.00 & 14.00 \\
\hline Employed & 50.00 & 22.00 & 19.00 \\
\hline White collar & 45.00 & 14.00 & 19.00 \\
\hline Blue collar & 5.00 & 8.00 & - \\
\hline Self-employed & 41.00 & 50.00 & 57.00 \\
\hline
\end{tabular}

Table 2. Prevalence of behavioural risk factor for NCDs.

\begin{tabular}{|c|c|c|c|c|c|c|c|}
\hline Characteristics & $\begin{array}{l}\text { Current } \\
\text { tobacco }\end{array}$ & $\begin{array}{c}\text { Harmful use } \\
\text { of alcohol }\end{array}$ & $\begin{array}{c}\text { Phisical } \\
\text { inactivity }\end{array}$ & $\begin{array}{c}\text { Sedentarity } \\
\text { of } \geq 7 \mathrm{~h}\end{array}$ & $\begin{array}{l}\text { Skipping } \\
\text { breakfast }\end{array}$ & $\begin{array}{c}\text { Late } \\
\text { dinner }\end{array}$ & Snacking \\
\hline Overall (\%) & 15.2 & 57.71 & 58.84 & 24.71 & 69.45 & 61.00 & 36.00 \\
\hline \multicolumn{8}{|l|}{ Area } \\
\hline $\begin{array}{c}\text { Urban } \\
\text { (Cocody) }\end{array}$ & 16.90 & 57.81 & 65.4 & 36.78 & 76.56 & 81.77 & 64.64 \\
\hline $\begin{array}{l}\text { Peri-urban } \\
\text { (Abobo) }\end{array}$ & 19.20 & 50.26 & 38.9 & 20.58 & 92.18 & 71.87 & 33.41 \\
\hline $\begin{array}{c}\text { Rural } \\
\text { (Yocoboué) }\end{array}$ & 9.30 & 1.58 & 10.6 & 6.29 & 39.15 & 28.84 & 2.42 \\
\hline \multicolumn{8}{|l|}{ Gender } \\
\hline Male & 34.93 & 66.10 & 32.81 & 20.30 & 78.16 & 69.00 & 18.12 \\
\hline Female & 2.22 & 11.83 & 38.56 & 22.24 & 55.02 & 55.23 & 47.96 \\
\hline
\end{tabular}




\section{Continued}

\begin{tabular}{cccccccc}
\hline Age group & & & & & & & \\
$19-29$ & 16.53 & 17.74 & 18.74 & 23.36 & 52.63 & 29.76 & 54.23 \\
$30-39$ & 18.86 & 30.58 & 20.62 & 20.81 & 75.22 & 37.05 & 36.07 \\
$40-49$ & 12.39 & 48.97 & 30.99 & 18.72 & 90.08 & 29.47 & 09.68 \\
$50-60$ & 9.19 & 14.30 & 47.75 & 21.91 & 84.61 & 3.71 & 0.00 \\
\hline
\end{tabular}

${ }^{*}$ Statistically significantly at $\mathrm{p}<0.05$.

\section{Alcohol consumption}

The prevalence of alcohol consumption of all the participants was $87.87 \%$. Concerning binge drinking, it was $57.71 \%$. Men consumption of alcohol was significantly higher (66.6\%) compared to the level among women (11.83\%). It's among the age group 40 - 49 years that the most significant prevalence was observed with $48.97 \%$.

\section{Physical inactivity}

Physical inactivity was prevalent $58.84 \%$ among the study participants. The highest prevalence (65.4\%) of low physical activity was from urban area (Cocody). Low practice of physical activity increased significantly with age: $18.74 \%$ for 19 - 29 years, $20.62 \%$ for 30 - 39 years, $31 \%$ for $40-49$ years, $47.75 \%$ for 50 and above. Also, women were more inactive than (38.56\%) than men $(32.81 \%)$.

\section{Sedentarity behaviour}

Participants reported $24.71 \%$ of waking time, in sedentary behavior (sitting for more than 7 hours). Urban area was associated to time spent in sedentary behaviours (Cocody; 36.78\%, Abobo; 20.58\% and Yocoboué; 6.29\%). Age was inversely associated with time spent in sedentary behaviors, it was decreased between 19 - 49 years old $(23.36 \%$ - 18.72\%) and increased after 50 and above (21.91\%). Among men and women, women were most positively associated with absolute time spent sitting than men (22.24\% vs $20.3 \%)$.

\section{Late dinner}

Taking a late dinner was high among the respondents $61 \%$. The late dinner intake concerned more than $3 / 4$ of the urban area of Cocody population. The prevalence was more than $25 \%$ across all age groups but it was lowest among the group of 50 and above $3.71 \%$. The male respondents were more to take late dinner than female (69\% vs $55.23 \%)$.

\section{Skipping breakfast}

The general prevalence of skipping breakfast was $69.45 \%$ among respondents. Skipping breakfast was most significant among peri-urban persons $(92 \%)$ than urban $(76.56 \%)$ and rural area (39.15\%). Compared to women $(55.02 \%)$, significantly higher prevalence was observed with men $78.16 \%$. Regarding age, the most significant prevalence was observed between 40 - 49 years old with $90.08 \%$.

\section{Snacking}

The prevalence was $36 \%$ among the study participants. The highest prevalence 
of snacking was from urban area (Cocody) (64.64\%).

Snacking decreased with age, $54.23 \%$ for $19-29$ years, $36.07 \%$ for $30-39$ years, significantly increase $9.68 \%$ for $40-49$ years, and decrease with age of 50 and above (84.61\%).

Concerning gender, the prevalence of women with snacking habit was significantly higher $(47.96 \%)$ than men $(18.12 \%)$.

\subsection{Prevalence of Biological Risk Factors}

\section{Overweight and obesity}

The rate of overweight and obesity of respondents were respectively $31.33 \%$ and $22.41 \%$. There was a positive associated between being overweight or obese and urban residence, age, female gender. About half of females were overweight or obese. We observed a high prevalence of among participants who aged above 40 years $49.33 \%$ and the respondents who living in urban area (Cocody) $59.6 \%$.

\section{Abdominal obesity}

The general prevalence of abdominal obesity about all participants was $52.96 \%$. Abdominal obesity was significantly important among female $70.93 \%$ than male $25.98 \%$. It was significantly increased with age $39.6 \%$ for $19-29 ; 54.72 \%$ for $30-$ 39 ; $69.42 \%$ for $40-49$; $89.23 \%$ for respondents aged 50 and above. The respondents living in urban and peri-urban area were with a higher prevalence respectively $69 \%$ and $52.61 \%$.

\section{Raised blood pressure}

The raised blood pressure among participants prevail $14.61 \%$. This prevalence significantly increased with age $2.62 \%$ for $19-29 ; 4.8 \%$ for $30-39 ; 9.7 \%$ for 40 $49 ; 16.9 \%$ for 50 and above. It's also noticed that male prevalent was significantly higher (34.93\%) than female (16\%).

\section{Raised blood sugar}

The prevalence of raised blood sugar among participants was $23.37 \%$. The prevalence among males was highest $13.97 \%$ than females $29.63 \%$. Also we observed a highest prevalence among group age of 50 - 60 years $67.69 \%$.

\section{Low HDL-Cholesterol}

The prevalence of low HDL-C of all participants was $18.51 \%$. We noticed that low HDL-C was most common among female $22.26 \%$ than among male at $12.88 \%$. It's also significantly increased with age no one for $19-29 ; 26.20 \%$ for 30 - 39; 33.06\% for 40 - 49; 38.49\% for respondents aged 50 and above. The respondents living in urban and peri-urban area were with a higher prevalence respectively $28.12 \%$ and $21.35 \%$ than rural $5.85 \%$. (Table 3 )

\subsection{Non-Communicable Diseases Associated Risk Factors}

Sociodemographics and behaviourals risk factors associated to non communicable diseases were presented on Table 4. Suffering from overweight and obesity among participants were being female (OR: 11.3), sedentarily (OR: 18.3), live in urban area (OR: 3.94) and skipping breakfast (OR: 3.65). Abdominal obesity 
Table 3. Prevalence of biological risk factors for NCDs.

\begin{tabular}{cccccc}
\hline Characteristics & $\begin{array}{c}\text { Overweight } \\
\text { or obesity }\end{array}$ & $\begin{array}{c}\text { Abdominal } \\
\text { obesity }\end{array}$ & $\begin{array}{c}\text { Raised } \\
\text { blood pressure }\end{array}$ & $\begin{array}{c}\text { Raised } \\
\text { blood sugar }\end{array}$ & $\begin{array}{c}\text { Low } \\
\text { HDL-C }\end{array}$ \\
\hline Overall (\%) & 40.95 & 52.96 & 14.61 & 23.37 & 18.51 \\
\hline Area & & & & & \\
Urban (Cocody) & 59.60 & 69.00 & 29.17 & 34.34 & 28.12 \\
Peri-urban (Abobo) & 42.09 & 52.71 & 23.93 & 22.39 & 21.35 \\
Rural (Yocoboué) & 25.07 & 27.04 & 15.05 & 13.23 & 05.85 \\
\hline Gender & & & & & \\
Male & 28.16 & 25.98 & 34.93 & 13.97 & 12.88 \\
Female & 49.42 & 70.93 & 16.00 & 29.63 & 22.26 \\
\hline Age group & & & & & \\
$19-29$ & 11.38 & 39.60 & 02.62 & 02.75 & 0.00 \\
$30-39$ & 28.08 & 54.72 & 04.80 & 22.46 & 26.20 \\
$40-49$ & 49.33 & 69.42 & 09.20 & 38.02 & 33.06 \\
$50-60$ & 9.68 & 89.23 & 16.90 & 67.69 & 38.46 \\
\hline
\end{tabular}

*Statistically significantly at $\mathrm{p}<0.05$.

Table 4. Multiple logistic regression analysis relating bio-chemical results with sociodemographic caracteristics and behaviourals risk factor.

\begin{tabular}{|c|c|c|c|c|c|}
\hline \multirow{2}{*}{ Variables } & Overweight/obesity & $\begin{array}{l}\text { Abdominal } \\
\text { Obesity }\end{array}$ & $\begin{array}{c}\text { Raised blood } \\
\text { Pressure }\end{array}$ & $\begin{array}{l}\text { Raised blood } \\
\text { sugar }\end{array}$ & $\begin{array}{c}\text { Low } \\
\text { HDL-C }\end{array}$ \\
\hline & $\begin{array}{c}\text { OR } \\
\text { [IC 95\%] }\end{array}$ & $\begin{array}{c}\text { OR } \\
\text { [IC 95\%] }\end{array}$ & $\begin{array}{c}\text { OR } \\
\text { [IC 95\%] }\end{array}$ & $\begin{array}{c}\text { OR } \\
\text { [IC 95\%] }\end{array}$ & $\begin{array}{c}\text { OR } \\
\text { [IC 95\%] }\end{array}$ \\
\hline \multicolumn{6}{|c|}{ Sociodemographics characteristic } \\
\hline \multicolumn{6}{|c|}{ Age (Years) } \\
\hline $19-29$ & $\begin{array}{c}2.33 \\
1.91 ; 4.32]^{\star}\end{array}$ & $\begin{array}{c}2.55 \\
{[1.33 ; 4.60]^{*}}\end{array}$ & 1 & 1 & 1 \\
\hline $30-39$ & $\begin{array}{c}4.45 \\
{[1.24 ; 5.48]^{\star}}\end{array}$ & $\begin{array}{c}6.67 \\
{[4.32 ; 12.6]^{*}}\end{array}$ & $\begin{array}{c}8.45 \\
{[1.52 ; 20.2]^{*}}\end{array}$ & $\begin{array}{c}1.46 \\
{[0.69 ; 2.86]}\end{array}$ & $\begin{array}{c}1.30 \\
{[0.79 ; 1.36]}\end{array}$ \\
\hline $40-49$ & $\begin{array}{c}5.62 \\
{[1.48 ; 21.4]^{*}}\end{array}$ & $\begin{array}{c}7.86 \\
{[5.40 ; 19.6]^{*}}\end{array}$ & $\begin{array}{c}13.4 \\
{[3.41 ; 40.9]^{*}}\end{array}$ & $\begin{array}{c}2.83 \\
{[1.39 ; 4.90]}\end{array}$ & $\begin{array}{c}1.93 \\
{[1.09 ; 2.06]}\end{array}$ \\
\hline $50-60$ & $\begin{array}{c}3.41 \\
{[1.01 ; 5.67]^{*}}\end{array}$ & $\begin{array}{c}7.68 \\
{[4.65 ; 21.2]^{*}}\end{array}$ & $\begin{array}{c}24.6 \\
{[12.3 ; 68.7]^{*}}\end{array}$ & $\begin{array}{c}3.48 \\
{[1.65 ; 8.69]}\end{array}$ & $\begin{array}{c}2.09 \\
{[0.69 ; 3.26]}\end{array}$ \\
\hline \multicolumn{6}{|c|}{ Area } \\
\hline Rural & 1 & 1 & 1 & 1 & 1 \\
\hline Urban & $\begin{array}{c}3.94 \\
{[0.52 ; 7.27]^{\star}}\end{array}$ & $\begin{array}{c}5.19 \\
{[1.09 ; 10.7]^{*}}\end{array}$ & $\begin{array}{c}1.91 \\
{[1.11 ; 3.27]}\end{array}$ & $\begin{array}{c}4.14 \\
{[1.27 ; 5.74]^{*}}\end{array}$ & $\begin{array}{c}1.15 \\
{[0.50 ; 1.86]}\end{array}$ \\
\hline \multicolumn{6}{|c|}{ Gender } \\
\hline Male & 1 & 1 & $\begin{array}{c}1.97 \\
{[1.41 ; 2.75]}\end{array}$ & 1 & 1 \\
\hline Female & $\begin{array}{c}11.3 \\
{[8.70 ; 24.4]^{*}}\end{array}$ & $\begin{array}{c}25.7 \\
{[12.9 ; 54.7]^{*}}\end{array}$ & $\begin{array}{c}0.90 \\
{[1.41 ; 2.75]}\end{array}$ & $\begin{array}{c}2.17 \\
{[0.80 ; 4.62]}\end{array}$ & $\begin{array}{c}1.55 \\
{[0.52 ; 2.45]}\end{array}$ \\
\hline
\end{tabular}




\section{Continued}

\begin{tabular}{|c|c|c|c|c|c|}
\hline \multicolumn{6}{|c|}{ Lifestyle } \\
\hline \multicolumn{6}{|c|}{ Tobacco } \\
\hline No & 1 & 1 & 1 & 1 & $\begin{array}{c}0.9 \\
{[0.65 ; 1.54]}\end{array}$ \\
\hline Yes & $\begin{array}{c}0.65 \\
{[0.54 ; 0.78]}\end{array}$ & $\begin{array}{c}0.51 \\
{[0.42 ; 0.60]^{\star}}\end{array}$ & $\begin{array}{c}1.74 \\
{[1.31 ; 2.64]}\end{array}$ & $\begin{array}{c}0.52 \\
{[0.59 ; 0.84]^{\star}}\end{array}$ & 1 \\
\hline \multicolumn{6}{|c|}{ Harmful alcohol } \\
\hline No & 1 & 1 & 1 & 1 & 1 \\
\hline Yes & $\begin{array}{c}2.38 \\
{[1.01 ; 4.74]^{*}}\end{array}$ & $\begin{array}{c}4.12 \\
{[0.80 ; 5.66]}\end{array}$ & $\begin{array}{c}2.98 \\
{[1.00 ; 8.91]}\end{array}$ & $\begin{array}{c}2.73 \\
{[1.03 ; 4.58]}\end{array}$ & $\begin{array}{c}1.33 \\
{[0.73-2.25]}\end{array}$ \\
\hline \multicolumn{6}{|c|}{ Level of physical activity } \\
\hline Vigorous & $\begin{array}{c}0.58 \\
{[0.41 ; 1.80]^{\star}}\end{array}$ & $\begin{array}{c}0.47 \\
{[0.25 ; 0.84]}\end{array}$ & 0.64 & 1 & $\begin{array}{c}0.83 \\
{[0.53 ; 1.25]}\end{array}$ \\
\hline Moderate & $\begin{array}{c}1.53 \\
{[0.81 ; 3.80]^{*}}\end{array}$ & $\begin{array}{c}1.09 \\
{[0.49 ; 2.88]}\end{array}$ & $\begin{array}{c}0.78 \\
{[0.90 ; 3.91]}\end{array}$ & $\begin{array}{c}2.67 \\
{[1.51 ; 4.55]}\end{array}$ & $\begin{array}{c}1.47 \\
{[1.23 ; 1.74]^{*}}\end{array}$ \\
\hline Light & $\begin{array}{c}2.93 \\
{[1.51 ; 5.71]^{*}}\end{array}$ & $\begin{array}{c}1.88 \\
{[0.90 ; 3.92]}\end{array}$ & 1 & $\begin{array}{c}3.01 \\
{[2.00 ; 4.51]}\end{array}$ & $\begin{array}{c}1.51 \\
{[0.73 ; 2.25]^{\star}}\end{array}$ \\
\hline \multicolumn{6}{|c|}{ Sedentarity time (sitting) } \\
\hline$<3 \mathrm{~h}$ & 1 & 1 & 1 & 1 & 1 \\
\hline $3-7 \mathrm{~h}$ & $\begin{array}{c}8.36 \\
{[3.53 ; 11.4]^{*}}\end{array}$ & $\begin{array}{c}4.80 \\
{[1.09 ; 5.38]}\end{array}$ & $\begin{array}{c}2.86 \\
{[0.90 ; 3.91]}\end{array}$ & $\begin{array}{c}2.64 \\
{[1.21 ; 3.40]}\end{array}$ & $\begin{array}{c}1.64 \\
{[0.73 ; 2.25]^{\star}}\end{array}$ \\
\hline$\geq 7 \mathrm{~h}$ & $\begin{array}{c}18.3 \\
{[10.6 ; 30.1]^{*}}\end{array}$ & $\begin{array}{c}5.41 \\
{[3.53 ; 12.5]}\end{array}$ & $\begin{array}{c}3.82 \\
{[1.08 ; 5.74]}\end{array}$ & $\begin{array}{c}4.57 \\
{[2.21-11.44]}\end{array}$ & $\begin{array}{c}2.04 \\
{[1.13 ; 4.65]^{\star}}\end{array}$ \\
\hline \multicolumn{6}{|c|}{ Eating behaviour } \\
\hline \multicolumn{6}{|c|}{ Day eating frequency } \\
\hline $1-2$ times & $\begin{array}{c}2.40 \\
{[1.04 ; 8.21]^{\star}}\end{array}$ & $\begin{array}{c}1.30 \\
{[0.75 ; 1.82]}\end{array}$ & $\begin{array}{c}0.82 \\
{[0.50 ; 1.66]}\end{array}$ & $\begin{array}{c}1.94 \\
{[1.10 ; 3.22]}\end{array}$ & $\begin{array}{c}1.69 \\
{[1.23 ; 2.15]}\end{array}$ \\
\hline 3 times & $\begin{array}{c}0.73 \\
{[0.54 ; 1.80]^{\star}}\end{array}$ & $\begin{array}{c}0.60 \\
{[0.37 ; 1.19]}\end{array}$ & $\begin{array}{c}0.47 \\
{[0.26 ; 0.86]}\end{array}$ & $\begin{array}{c}0.88 \\
{[0.64 ; 1.36]}\end{array}$ & 1 \\
\hline$>3$ times & $\begin{array}{c}2.77 \\
{[1.91 ; 5.20]^{*}}\end{array}$ & $\begin{array}{c}2.04 \\
{[0.9 ; 4.25]}\end{array}$ & $\begin{array}{c}0.97 \\
{[0.33 ; 2.16]}\end{array}$ & $\begin{array}{c}1.80 \\
{[0.69 ; 4.92]}\end{array}$ & 1 \\
\hline Snacking & $\begin{array}{c}1.53 \\
{[1.08 ; 4.80]}\end{array}$ & $\begin{array}{c}1.17 \\
{[0.95 ; 2.18]}\end{array}$ & 1 & $\begin{array}{c}2.18 \\
{[0.55 ; 4.78]}\end{array}$ & 1 \\
\hline $\begin{array}{l}\text { Skipping } \\
\text { breakfast }\end{array}$ & $\begin{array}{c}3.65 \\
{[1.61 ; 8.44]}\end{array}$ & 1 & 1 & $\begin{array}{c}2.94 \\
{[1.38 ; 7.27]}\end{array}$ & $\begin{array}{c}1.87 \\
{[0.90 ; 3.01]}\end{array}$ \\
\hline Late dinner & $\begin{array}{c}3.36 \\
{[1.51 ; 5.75]}\end{array}$ & $\begin{array}{c}2.12 \\
{[1.04 ; 8.2]}\end{array}$ & $\begin{array}{c}0.79 \\
{[0.59 ; 1.08]}\end{array}$ & $\begin{array}{c}2.05 \\
{[1.82 ; 5.08]}\end{array}$ & $\begin{array}{c}2.02 \\
{[1.19 ; 2.21]}\end{array}$ \\
\hline
\end{tabular}

${ }^{*}$ Statistically significantly at $\mathrm{p}<0.05$.

were associated to increasing age, being woman, live in urban area, sedentarity and harmful alcohol. About abdominal obesity, women were almost 26 times more to suffer from it than men (OR: 25.7). Having raised blood pressure was associated with age, binge drinking and overweight/obesity. Raised blood pres- 
sure increased with age: 30 - 39 years (OR: 8.45), 40 - 49 years (OR: 13.4), 50 years and above (AOR: 24.6). The most important factors of raised blood sugar were sedentary (OR: 4.57) and skipping breakfast (OR: 2.94). The associated factors of low HDL-C were age of 50 years and above (OR: 2.09), sedentariness (OR: 2.04) and late dinner (OR: 2.02).

\subsection{Prevalence (\%) of Multiple NCDs Risk Factors among Study Population}

In Figure 1, it's showed the prevalence of multiple NCD risk factors among all participants.

We observed that just a small proportion of participants (2.3\%) were free of NCD risk factors. Also $80 \%$ of them had at least two NCD risk factors. The participants had on average of four (4) NCD risk factors.

\section{Discussion}

Our results showed a high prevalence of NCDS risk factor among study population. Concerning behavioral risk factors, $15.2 \%$ of participant consumed tobacco. This prevalence represented the half of those which was in France (32\%) [16].

About alcohol, $57.71 \%$ of participants have used alcohol. This consumption reached those observed in previous surveys leaded in 2015 in Ivory Cost [17].

Alcohol and tobacco were most prevalent among male than women. Similar results were observed in others study [18] [19].

Physical inactivity and sedentariness prevailed respectively $58.84 \%$ and $24.71 \%$. And women's prevalence was the most important in the two cases. Current study in Australia has showed the same remarks [20].

Certain dietary habits like skipping breakfast, having late dinner and snacking have been found among study population. Two behaviors such as skipping breakfast and late dinner were more prevalent among men than women [21].

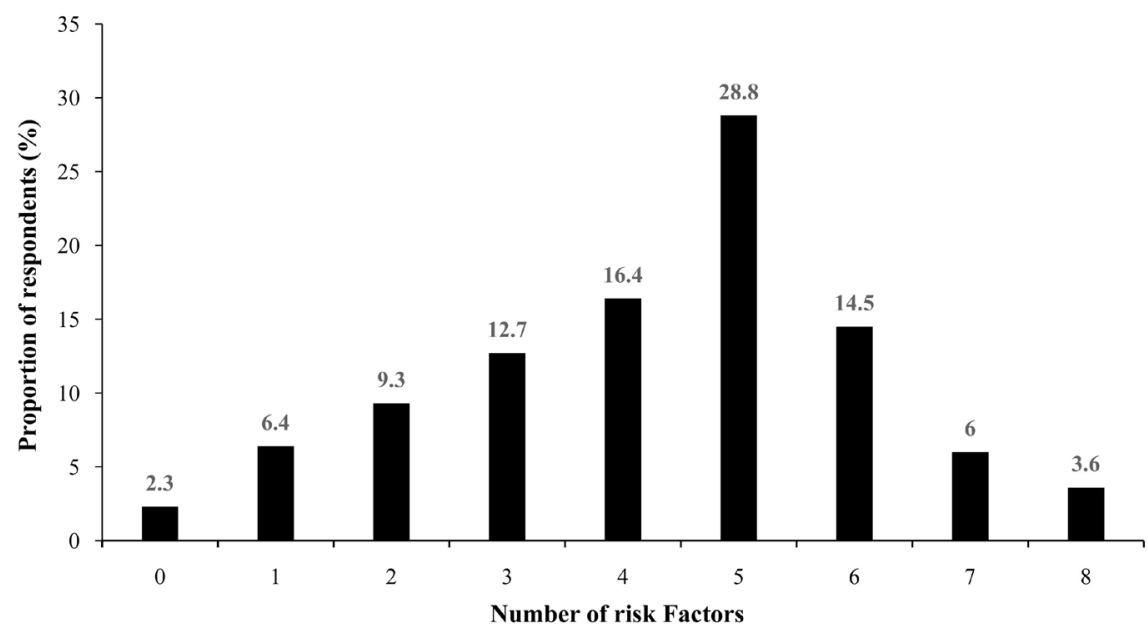

Figure 1. Prevalence of multiple risk factors among study population. 
Many countries of Asia have accessed the prevalence of some NCDs risk factor [22].

Concerning anthropometric risk factors, our study have showed in this case that the prevalence of overweigh and obesity were respectively $31.33 \%$ and $22.41 \%$ (55.47\% the two together). This rate is close to those observed with Olamedji and coworker's study [23]. But lower than those reported in United States (60\%) [24].

Data showed a higher prevalence of overweight and obesity in urban (Cocody, 59.6\%) and peri-urban (Abobo; 42.09\%) in contrast to rural area of Yocoboué (25.07\%). Rarau and co-worker in 2017 reported that overweight and obesity prevalence were the highest in urban living place relative to rural place [25]. And again our results were in accordance to data from survey reported in Burkina Faso [26] [27].

In term of abdominal obesity ( $\mathrm{AO})$, it's was found high rate in urban living place (Cocody) than peri-urban (Abobo) and rural (Yocoboué) area. The prevalence of AO was also high among women than men. Previous study in India has showed the same results [28].

We found certain biological risk factors among the participants of the study. High blood pressure was observed among the population. It's less than quarter (14.61\%) of participants who were concerned by this case. This prevalence was relatively high and reached those revealed by Sackou and et al. in Abidjan [29].

Raised blood pressure in our study was prevalent with men than women. Similar results was observed by Everett and Zajacova who have determined than male was most hypertensive [30] [31].

The prevalence of high blood sugar was 23.37 for the global population of this study. This rate is reached to those found in South African [32] [33].

Gender distribution of high blood sugar in our study is unsteady. A study in South Africa and other in Senegalese revealed higher rate among women [33] [34]. But in others surveys in Nigeria and Tunisia showed the contrary [35] [36].

Concerning HDL-C, we have observed in general a prevalence of $18.51 \%$. This prevalence increased among women $22.26 \%$ than men (12.88\%). Data from analysis among African American adults has described a high rate of HDL-C with women [37].

The results concerning association between certain sociodemographic caracteristics (age, gender, residence place), lifestyle (alcohol and tobacco consumption, physical activity and sedentariness), eating behavior (eating frequency, skipping breakfast, late dinner and snacking) and anthropometric and biological risk factors (overweight/obesity, abdominal obesity, high blood pressure, high blood sugar and low HDL-C) have been demonstrated in the study.

Being overweight or obese was associated with much of the risk factors but the most strongly associated one was female gender. The same observation was found in a study in kaduna [38] and others authors have showed similar results [39]. This female predominance could be explained by pregnancies and sociocultural motivations [40]. These differences among female may due to the fact 
that in subsaharan countries being overweight or obese is a sign of beauty, fertility, well-being [39]. Another explanation could be attributable to kind of daily activities practiced by women which was recognize as a light physical activity and they also prolonged sitting's time [41].

Our investigation about abdominal obesity was associated with greater odds of female gender. Women were about 26 times to be concerned by AO. Certains authors have found that these results are in line with ours [42]. Several ways can be explained this difference, first difference in sex steroid hormone cause divergence in body composition [43]. Secondly contrary to men, women have a genetic ability to accumulate fat [44]. Visceral fat and post partum abdominal caused by pregnancy were blamed [13]. With women, during post menopausal the body fat redistribution in abdominal area was important [45].

In our study; many factors were associated to hypertension such as age, urban area, male gender, tobacco and alcohol consumption, prolonged sitting time ( $\geq 7$ hours). But the most strongly associated factor of high blood pressure mainly concerned age and particularly age group of 50 - 60 years old. That observation was found in other surveys [46]. Also it was confirmed in a study from cameroon [47] [48].

These results could be the fact that when age increases, the cells get old and arteries become rigid. Therefore this rigidity makes difficult the blood circulation which finally increases blood pressure [49].

Sedentary time (sitting time $\geq 7$ hours) was main risk factor associated to raised blood sugar, it "s followed by urban residence place and light physical activity. The probable explanation of this association was due that certainly it's plausible that excess body fat could be the reason in part why sedentary lifestyle lead to a risk of raised blood sugar. Physical activity has resulted an acute contraction of active skeletal muscle which improves insulin action [50] [51].

Finding from participants of study revealed that the most important factor associated to low HDL-C was age (50 - 60 years old). Previous study observed the same results [52] [53].

This result could be due to the fact that when age increase, it causes biological change [54].

\section{Conclusions}

In conclusion, we observed that the population of study whether it's from the urban, peri-urban area or rural area, has some behavioral risk factors for NCDs. Those were very important were alcohol (respectively $57.81 \% ; 50.26 \% ; 1.58 \%$ ), physical inactivity (respectively 65.4\%; 38.9\%; 10.6\%), sedentariness (sitting at least 7 h) $(36.78 \%, 20.58 \%, 6.29 \%)$ and late dinner $(81.77 \%, 71.87 \%, 28.84 \%)$. Concerning biological risk factors for NCDs, we reported a rural-urban positive gradient for the prevalence of all of them.

Also, we have seen some interesting patterns of relation between socio-demographic, behavioral risk factors and biochemical risk factors. The most commons 
behavioral risk factors associated to NCDs were age, urban area, female gender, harmful alcohol, sedentary, physical inactivity and late dinner. We noted that biological risk factors were most important with females than males. Overweight/obesity and abdominal obesity were most positively associated to the female gender, raised blood pressure to age particularly (50 - 60 years). Those of raised blood sugar were most associated with sedentary time $(\geq 7 \mathrm{~h})$ and low HDL-C to age (50 - 60 years). There was also observed a significant level of clustering of NCD risk factors and that concerned $80 \%$ of the participants. This study shows that the nutrition transition is ongoing in Ivory Coast and NCDs could be reduced substantially. So public health interventions against NCDs might be provided by promoting an active lifestyle, a more adequate diet and using the urban residence place as a platform of fighting.

\section{Conflicts of Interest}

The authors declare no conflict of interest.

\section{References}

[1] Maire, B. and Delpeuch, F. (2004) La transition nutritionnelle, l'alimentation et les villes dans les pays en développement. Cahier de P Agriculture, 13, 23-30.

[2] Popkin, B.M. (1993) Nutritional Patterns and Transitions. Population and Development Review, 19, 138-157. https://doi.org/10.2307/2938388

[3] Knapp, V.J. (2000) Diet and Disease during Europe's Agricultural and Industrial Revolutions. Nutrition Health, 13, 185-198.

[4] Pomerleau, J., McKee, M., Lobstein, T. and Knai, C. (2003) The Burden of Disease Attributable to Nutrition in Europe. Public Health Nutrition, 6, 453-461.

https://doi.org/10.1079/PHN2002456

[5] Benjelloun, S. (2002) Nutrition Transition in Morocco. Public Health Nutrition, 5, 135-140. https://doi.org/10.1079/PHN2001285

[6] Holdsworth, M., Gartner, A., Landais, E., Maire, B. and Delpeuch, F. (2004) Perceptions of Healthy and Desirable Body Size in Urban Senegalese Women. International Journal of Obesity Related Metabolic Disorder, 28, 1561-1568. https://doi.org/10.1038/sj.ijo.0802739

[7] World Health Organization (2014) Global Status Report on Noncommunicable Disease 2014. World Health Organization, Geneva, 298.

[8] World Bank Group Data (2015) World Bank Country and Lending Groups. http://data.worldbank.org/about/country-and-lending-groups

[9] Zimmet, P. (2000) Globalization, Coca-colonization and the Chronic Disease Epidemic: Can the Doomsday Scenario Be Averted? Journal of International Medicine, 247, 301-310. https://doi.org/10.1046/j.1365-2796.2000.00625.x

[10] Iser, D.J. and Avera, K. (1993) Has Westernization Influenced Serum Cholesterol Levels in Bougainvillian Males? PNG Medicine Journal, 36, 311-315.

[11] World Health Organization (2010) Global Database on Body Mass Index 2010. World Health Organization, Geneva. http://www.who.int/bmi

[12] World Health Organization (2005) Questionnaire mondial sur la pratique d'activités physiques (GPAQ). Guide pour l'analyse. En ligne 
http://www.who.int/chp/steps/GPAQ_Analysis_Guide_FR.pdf

[13] World Health Organization (2008) Waist Circumference and Waist-Hip Ratio. World Health Organization, Geneva.

https://apps.who.int/iris/bitstream/handle/10665/44583/9789241501491_eng.pdf

[14] World Health Organization (1978) World Health Organization Expert Committee on Arterial Hypertension. Technical Report Series No.628, World Health Organization, Geneva.

[15] Wayne, D.W. (2005) Biostatistics: A Foundation for Analysis in the Health Sciences. 8th Edition, John Wiley and Sons, Inc., Hoboken.

[16] Andler, R., Richard, J.B., Guignard, R., Quatremère, G., Verrier, F., Gane, J. and Nguyen Thanh, V. (2019) Baisse de la prévalence du tabagisme quotidien parmi les adultes: Résultats du Baromètre de Santé publique France 2018. Bulletin Épidémiologie Hebdomadaire, No. 15, 271-277.

[17] Yao, K.M., Adou, K.F.J.-B., Bakou, N.F., Camara, P.A., Tako, N.A. and Seri, B. (2015) Évolution de la consommation des Boissons alcooliques vendues en côte D’ivoire. European Sciences Journal, 11, 1-16, 16 p.

[18] Hill, C. (2012) Épidémiologie du tabagisme. La revue du praticien, 62, 325-329.

[19] Mondo, C.K., Otim, M.A., Akol, G., Musoke, R. and Orem, J. (2013) The Prevalence and Distribution of Non-Communicable Diseases and Their Risk Factors in Kasese District. Uganda Cardiovascular Journal of Africa, 24, 52-57.

https://doi.org/10.5830/CVJA-2012-081

[20] Tran, B., Falster, M.O., Douglas, K., Blyth, F. and Jorm, L.R. (2014) Health Behaviours and Potentially Preventable Hospitalisation: A Prospective Studyof Older Australian adults. PLoS ONE, 9, e93111. https://doi.org/10.1371/journal.pone.0093111

[21] Hébel, P. (2012) Comportements et consommations alimentaires en France. No. LI32, Editions TEC et DOC, Paris, 18 p.

[22] Aryal, K.K., Mehata, S., Neupane, S., Vaidya, A., Dhimal, M. and Dhakal, P. (2015) The Burden and Determinants of Non-Communicable Diseases Risk Factors in Nepal: Findings from a Nationwide STEPS Survey. PLoS ONE, 10, e0134834. https://doi.org/10.1371/journal.pone.0134834

[23] Oladimeji, A., Fawole, O.I., Nguku, P. and Nsubuga, P. (2012) Prevalence and Factors Associated with Hypertension and Obesity among Civil Servants in Kaduna, Kaduna State, June 2012. Pan Africa Medical Journal, 18, Article No. 13. https://doi.org/10.11604/pamj.supp.2014.18.1.3260

[24] Li, C., Ford, E.S., McGuire, L.C. and Mokdad, A.H. (2007) Increasing Trends in Waist Circumference and Abdominal Obesity among US Adults. Obesity, 15, 216. https://doi.org/10.1038/oby.2007.505

[25] Rarau, P., Vengiau, G., Gouda, H., Phuanukoonon, S., Kevau, H.I., Bullen, C., et al. (2017). Prevalence of Non-Communicable Disease Risk Factors in Three Sites across Papua New Guinea: A Cross-Sectional Study. BMJ Global Health, 2, Article ID: e000221. https://doi.org/10.1136/bmjgh-2016-000221

[26] Ouédraogo, H.Z., Fournet, F., Martin-Prével, Y., Gary, J. and Henry, M.C. (2008) Socio-Spatial Disparities of Obesity among Adults in the Urban Setting of Ouagadougou, Burkina Faso. Public Health Nutrition, 11, 1280-1287. https://doi.org/10.1017/S1368980008002504

[27] Niakara, A., Fournet, F. and Gary, J. (2007) Hypertension, Urbanization, Social and Spatial Disparities: A Cross-Sectional Population-Based Survey in a West African 
Urban Environment (Ouagadougou, Burkina Faso). Transactions of the Royal Society of Tropical Medicine and Hygiene, 101, 1136-1142. https://doi.org/10.1016/j.trstmh.2007.07.002

[28] Thankappan, K.R., Shah, B., Mathur, P., Sarma, P.S., Srinivas, G., Mini, G.K., Soman, M.D.B. and Vasan, R.S. (2010) Risk Factor Profile for Chronic Non Communicable Diseases: Results of a Community-Based Study in Kerala, India. Indian Journal of Medicine Research, 131, 53-63.

[29] Sackou, J.K., Tiadé, M.L., Hounsa, A.A., Malik, S.K., Coulibaly, M., Desquith, A.A., Kadjo, F.K., Agoua, S.A., Oga, S. and Kouadio, L.K. (2019) Prevalence and Factors Associated with Hypertension in Anonkoi 3, a Peri-Urban Area in Abidjan (Côte d'Ivoire). Journal of Public Health in Africa, 10, 1106-1011. https://doi.org/10.4081/jphia.2019.1106

[30] Everett, B. and Zajacova, A. (2015). Gender Differences in Hypertension and Hypertension Awareness among Young Adults. Biodemography and Social Biology, 61, 1-17. https://doi.org/10.1080/19485565.2014.929488

[31] Ratovoson, R., Rasetarinera, O.R., Andrianantenaina, I., Rogier, C., Piola, P. and Pacaud, P. (2015) Hypertension, a Neglected Disease in Rural and Urban Areas in Moramanga, Madagascar. PLoS ONE, 10, e0137408.

https://doi.org/10.1371/journal.pone.0137408

[32] Erasmus, R.T., Soita, D.J. and Hassan, M.S. (2012) High Prevalence of Diabetes Mellitus and Metabolic Syndrome in a South African Coloured Population: Baseline Data of a Study in Bellville, Cape Town. South African Medical Journal, 102, 841-844. http://doi.org/10.7196\%2FSAMJ.5670

[33] Peer, N., Steyn, K., Lombard, C., Lambert, E.V., Vythilingum, B. and Levitt, N.S. (2012) Rising Diabetes Prevalence among Urban-Dwelling Black South Africans. PLoS ONE, 7, e43336. https://doi.org/10.1371/journal.pone.0043336

[34] Duboz, P., Chapuis-Lucciani, N., Boëtsch, G. and Gueye, L. (2012) Prevalence of Diabetes and Associated Risk Factors in a Senegalese Urban (Dakar) Population. Diabetes and Metabolism, 38, 332-336. https://doi.org/10.1016/j.diabet.2012.02.011

[35] Ejim, E.C., Okafor, C.I., Emehel, A., Mbah, A.U., Onyia, U., Egwuonwu, T., et al. (2011) Prevalence of Cardiovascular Risk Factors in the Middle-Aged and Elderly Population of a Nigerian Rural Community. Journal of Tropical Medicine, 2011, Article ID: 308687. https://doi.org/10.1155/2011/308687

[36] Hammami, S., Mehri, S., Hajem, S., Koubaa, N., Souid, H. and Hammami, M. (2012) Prevalence of Diabetes Mellitus among Non Institutionalized Elderly in Monastir City. BMC Endocrine Disorders, 12, Article No. 15. https://doi.org/10.1186/1472-6823-12-15

[37] Harman, J.L., Griswold, M.E., Jeffries, N.O., Sumner, A.E., Sarpong, D.F., Akylbekova, E.L., Walker, E.R., Wyatt, S.B. and Taylor Jr., H.A. (2011) Age Is Positively Associated with HDL-Cholesterol among African Americans in Cross-Sectional Analysis: The Jackson Heart Study. Journal of Clinical Lipidology, 5, 173-178. https://doi.org/10.1016/j.jacl.2011.02.002

[38] World Health Organization (2014) Global Status Report on Non-Communicable Diseases 2014. World Health Organization, Geneva.

[39] Sagna, Y., Yanogo, D.A.R., Tiéno, H., Guira, O. and Bagbila, A.P. (2014) Obesity and Metabolic Syndrome in a Burkina Faso Urban Area: Prevalence, Associated Factors and Comorbidities. Journal of Nutritional Disorders \& Therapy, 4, Article No. 141. https://doi.org/10.4172/2161-0509.1000141

[40] Azoh, A.J.C., Azoh, A.J.C. and Lokrou, A. (2009) Influence de la paritésur le tour de 
taille chez la noire africaine en Côte-d'Ivoire. À propos de 181 cascolligésdans le service d'endocrinologiediabétologie du CHU de Yopougon Abidjan. Diabetes \& Metabolism, 35, A45. https://doi.org/10.1016/S1262-3636(09)71869-5

[41] Walker, A.R., Adam, F. and Walker, B.F. (2001) World Pandemic of Obesity: The Situation in Southern African Populations. Public Health, 115, 368-372. https://doi.org/10.1038/sj.ph.1900790

[42] Bazzano, L.A. (2005) Dietary Intake of Fruit and Vegetables and Risk of Diabetes Mellitus and Cardiovascular Disease. World Health Organization, Geneva. http://www.who.int/dietphysicalactivity/publications/f\%26v_cvd_diabetes.pdf

[43] Derby, C.A., Zilber, S. and Brambilla, D. (2006) Body Mass Index, Waist Circumference and Waist to Hip Ratio and Change in Sex Steroid Hormones: The Massachusetts Male Ageing Study. Clinical Endocrinology, 65, 125-131. https://doi.org/10.1111/j.1365-2265.2006.02560.x

[44] Lasky, D., Becerra, E., Boto, W., Otim, M. and Ntambi, J. (2002) Obesity and Gender Differences in the Risk of Type 2 Diabetes Mellitus in Uganda. Nutrition, 18, 417-421. https://doi.org/10.1016/S0899-9007(01)00726-2

[45] Toth, M.J., Tchernof, A., Sites, C.K. and Poehlman, E.T. (2000) Effect of Menopausal Status on Body Composition and Abdominal Fat Distribution. International Journal of Obesity, 24, 226-231. https://doi.org/10.1038/sj.ijo.0801118

[46] Pereira, M., Lunet, M., Azavzdo, A. and Barros, H. (2009) Differences in Prevalence, Awareness, Treatment and Control of Hypertension between Developing and Developed Countries. Journal of Hypertension, 27, 963-975. https://doi.org/10.1097/HJH.0b013e3283282f65

[47] Musinguzi, G. and Nuwaha, F. (2013) Prevalence, Awareness and Control of Hypertension in Uganda. PLoS ONE, 8, e62236. https://doi.org/10.1371/journal.pone.0062236

[48] Doulougou, B. (2014) Hypertension arterielle dans la population adulte du Burkina Faso: prevalence, detection, traitement et controle. These PhD Sante Publique option epidemiologie, Universite de Montreal, Quebec.

[49] Abebe, S.M., Berhane, Y., Worku, A. and Assefa, A. (2014) Diabetes Mellitus in North West Ethiopia: A Community Based Study. BMC Public Health, 14, Article No. 97. https://doi.org/10.1186/1471-2458-14-97

[50] Dunstan, D.W., Kingwell, B.A., Larsen, R., Healy, G., Cerin, E., Hamilton, M.T., Shaw, J. E., Bertovic, D. A., Zimmet, P. Z., Salmon, J. and Owen, N. (2012) Breaking up Prolonged Sitting Reduces Postprandial Glucose and Insulin Responses. Diabetes Care, 35, 976-983. https://doi.org/10.2337/dc11-1931

[51] Manohar, C., Levine, J.A., Nandy, D.K., Saad, A., Dalla, M.C., McCrady-Spitzer, S.K., Basu, R., Cobelli, C., Carter, R.E., Basu, A. and Kudva, Y.C. (2016) The Effect of Walking on Postprandial Glycemic Excursion in Patients with Type 1 Diabetes and Healthy People. Diabetes Care, 35, 2493-2499.

https://doi.org/10.2337/dc11-2381

[52] Gradidge, P.J.-L., Norris, S.A., Jaff, N.G. and Crowther, N.J. (2016) Metabolic and Body Composition Risk Factors Associated with Metabolic Syndrome in a Cohort of Women with a High Prevalence of Cardiometabolic Disease. PLoS ONE, 11, e0162247. https://doi.org/10.1371/journal.pone.0162247

[53] Sumner, A.E., Zhou, J., Doumatey, A., Imoisili, O.E., Acheampong, J., Oli, J., et al. (2011) Low HDL-Cholesterol with Normal Triglyceride Levels is the Most Common Lipid Pattern in West Africans and African Americans with Metabolic Syndrome: Implications for Cardiovascular Disease Prevention. CVD Preventive Control, 5, 
75-80. https://doi.org/10.1016/j.cvdpc.2010.07.003

[54] Berrougui, H., Isabelle, M., Cloutier, M., Grenier, G. and Khalil, A. (2007) Age-Related Impairment of HDLmediated Cholesterol Efflux. Journal of Lipid Research, 48, 328-336. https://doi.org/10.1194/jlr.M600167-JLR200 